\title{
Educating Architects in Turkish Culture, Gains and Loses: A Historical Perspective
}

\author{
Ibrahim Numan ${ }^{1, *}$, and Revianto Budi Santosa ${ }^{2}$ \\ ${ }^{1}$ Fatih Sultan Mehmet Vakif University, Turkey \\ ${ }^{2}$ Department of Architecture, Universitas Islam Indonesia, Indonesia
}

\begin{abstract}
Ottoman and Turkish architecture have exhibited a constancy and change in the course of history. Nevertheless these changes can only be understood by taking architectural education into account. Here it will be tried to discuss the gains and losses between the increase in the degree of architectural education/specialized knowledge and the blindness to the value judgements of the society and their reflection on the Turkish architecture. The edifice can not be separated from the architect, architect from the society; society and education from the idea. An architect is educated by society. Architect in turn is the product of the common idea of the civilisation he or she is affiliated to. Even a small diversity in the depth of belief or change in the approach in life style brings a deviation in the understanding of arts and architecture consequently architectural education also experience gains and losses along with it.
\end{abstract}

\section{Introduction}

Architecture is a social art, conceived and realized in a society. An edifice can not be separated from its architect, in turn, the architect from the society he or she belongs to; as well as the architect's education is also developed from an idea nurtured in a society. To certain extent, an architect is educated by society. An architect, in turn, is the product of the common idea of the civilisation he or she is affiliated to.

In the dynamics of a society, a diversity in the depth of belief or change in the approach in life style brings a deviation in the understanding of arts and architecture consequently architectural education also experience gains and losses along with it.

Architecture in Turkey experience a remarkable dynamics along with major changes in its society. Following the Anatolian Seljukids in 1071-1308, Ottomans in 1299-1923 (comprising Formation, Classical, Reformation, and Westernization periods), Republic of Turkey 1923- date (Modernization), Turkish culture have experienced a great range of diversity in social value and in belief systems which are profoundly reflected on its architecture.

\section{Critical Threshold In Ottoman Architecture}

Sign of change in Ottoman architecture appeared during the reign of Ahmet III (r. 1703-30). Intending to broaden the empire's political and cultural contacts, he sent ambassadors to Paris, Vienna, Moscow and Warsaw. French or Versailles in particular was primarily appealing. The ambassador, Mehmet Efendi returned from Paris with twelve engravings of Versailles, inspiring the ruler to build garden, palaces and fountain in Istanbul. The most impressive building of this period is the Fountain of Ahmet III situated in front of Bab i Humayun or the Imperial Gate of Topkapi Palace.

Further steps of Westernization were taken in the construction of Nuruosmaniye Câmii (1748-1755) next to the Grand Bazaar in Istanbul. This mosque and its religious complex (kulliye) was built under the order of Sultan Mahmut I and completed during the reign of Sultan Osman III, therefore, the mosque was named after him. The design and construction of this mosque was carried out by Mimar Mustafa Aga and his assistant Simon Kalfa, a non-muslim Greek.

Nuruosmaniye represents a threshold between the Classical Ottoman and the Westernization period. It was the first major Ottoman mosque Ottoman to exemplify the new baroque style introduced from Europe. It consists essentially of a square room covered by a large dome resting on four pillars on the corners and four slightly pointed arches on the walls, boldly appear in the interior as well as in the exterior.

The mihrab and the courtyard preceeding the main prayer hall have distinct shape. The mihrab is fashioned like a semi circular apse prominently appear to the qibla façade. A porch with five bays standing on the entrance side facing a semi circular courtyard enclosed by an arcade covered with nine domes.

*orresponding author: inuman@fsm.edu.tr 


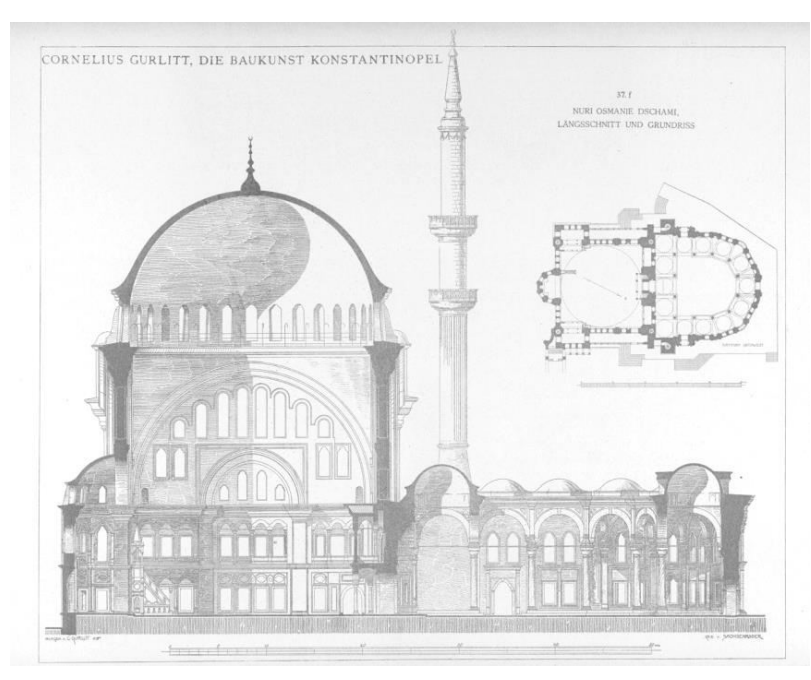

Fig. 1. Nurosmaniye Mosque in Istanbul. Source: Gurlitt, 1912.

Baroque and Roccoco elements such as the $\mathrm{C}$ and $\mathrm{S}$ curves in the plans and architectural elements, and by rococo ornamentation with leaf forms, scallops, and volutes further emphasize the novelty of characters of this mosque. Later, this newly introduced style was applied in a number of imperial mosques in Istanbul, such as Laleli Mosque (1783) and Buyuk Selimiye Mosque (1805) in Uskudar.

Changes towards to westernization have reflected almost in every aspect of the society from the way of life to dressing to ornamentation; hence, from buildings to education in architecture.

\section{Empire, Eclecticism Period (1808-1876)}

Under the influence of the foreign architects and nonmuslim builders ideas have been developed which divert Ottoman architecture towards eclecticism. These ideas were mainly had been constructed on a discourse that Ottoman architecture should be enriched by reflecting different details of different styles of the different regional areas that empire was spreading.

Early in this period, to cope with the technological advancement especially in the military area Sultanate have increase the relationships with the Europe. During the reign of Sultan Selim III (1789-1807), Yirmisekiz Çelebi Mehmet Efendi was sent to Paris on a diplomatic mission. He conveyed messages about his experiences and contacts in Europe describing opera, palaces, landscape and interior architecture beside other issues. Plans and drawings of palaces and other buildings were brought as samples of different European styles. Which consisted models for new architecture in Istanbul.

Mainly non-Muslims were active in spreading this idea. The Balyan family of Armenian origin played important roles by serving Ottoman sultans during the 18 th and 19th centuries for five generations. Some prominent members of Balyan families studied architecture in Paris. Based on Neo Classical knowledge and education, they developed a unique architectural style by blending European baroque and imperial styles with Ottoman architecture and oriental ornamental style.

Sultan Mahmut II's wife, mother of Sultan Abdülaziz, Pertevniyal Valide Sultan comissioned a mosque in the district of Aksaray in İstanbul in 18691871. This mosque is a good example of these kind of patch-works executed by a patch-work group of nonmuslims.

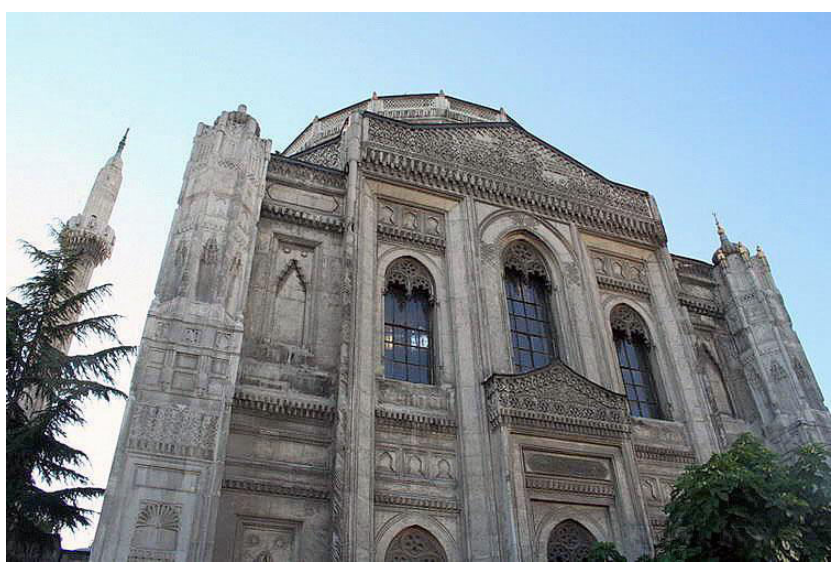

Fig. 2. Petrevniyal Valide Sultan Mosque, Aksaray, Istanbul. Source of Picture: Avniyazici \& Gothika, commons.wikimedia.org.

The Mosque's chief architect was the Italian Montani Pasha. Its plan was drawn by the Armenian Sarkis Balyan, while Hagop Balyan participated in the preparation, supported by the draftsman Osep. Application and site management was undertaken by naster builder Bedros Kalfa, the bricklayer Ohannes and carpenter Dimitri.

Other mosques bearing this style were Nushretiye Mosque (1826), Dolmabahçe Mosque (1855) and Buyuk Mecidiye or Ortakoy Mosque (1856). A number of bulding serving non religious purposes such as, Dolmabahçe Palace (1856), Çırağan Palace (1867), Beylerbeyi Palace (1861) and Selimiye Barracks (1828) were also employed this style.

The involvement of non-muslim European architects further promoted under the Reform Policy or known as Tanzimat initiated by Sultan Mahmut II (r. 1808-1839) and his son Sultan Abdulmecit I (r. 1839-1861) that began in 1839 .

During this Tanzimat Era, some European architects like the Italian Raimondo D'Aronco (1857-1932) and the French Alexandre Vallaury (1850-1921) participated both in practice by developing certain distinct style of Oriental or Ottoman Art Noveau (Freely, 2011). They were also involved architectural education teaching muslim and non-muslim students alike. 


\section{Usul-I Mimari-I Osmani And The Rationalization Of Ottoman Architecture}

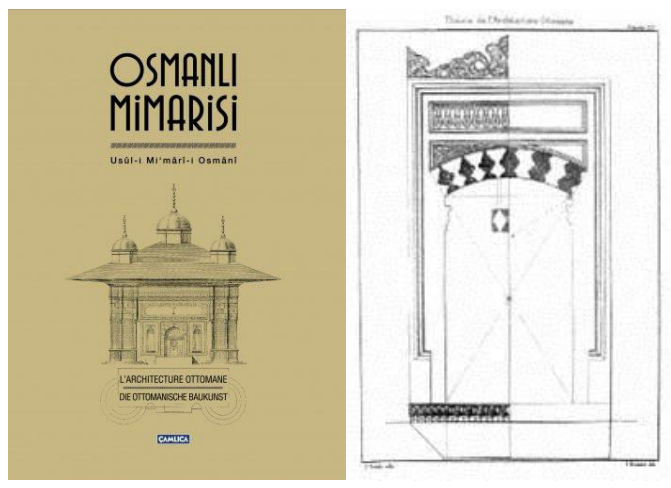

Fig. 3. Book Usul-i Mimari-i Osmani.

Usul-i Mimari-i Osmani or Principles of Ottoman Architecture was prepared by the collaboration of a group under the directorship of the Minister of Trade and Public Works, İbrâhim Edhem Paşa to represent Ottoman empire in the World Exhibition in Vienna 1873, beside two other important books. Although the purpose was to exhibit Ottoman Styles to the world it had been and still used as a one of the text books in the education of architects. The book illustrates the Ottoman Architecture with details. Technical Documents constituting a separate section entitled "The Theory of Ottoman Architecture", was provided by Pietro Montani (or Montani Efendi), an Ottoman Levantine artist of Italian origin. Montani also executed most of the drawings and color plates. Other collaborators in preparation were Adolphe Maillard, few plans by Marie de Launay and some additional renderings of decorative components by the French artist Eugène Maillard and the Ottoman Armenian painter Bogos Chachian (Nalbantoğlu, 1988).

Baydar (2004) considers the publication of Usul-i Mimari-i Osmani "the time of the birth of Ottoman nationalism with the aim of providing social cohesion between the various ethnic and religious groups that constituted the empire".

This monumental book marks the general shift of architectural historiography and theoretical frameworks from an Islamic to a national identity. It primarily consits of a section on historical development of Ottoman Architecture and another section on principles of architectural orders. According to the former section, Ottoman architecture undergoes three successive phases. Started from relatively obscure beginnings, Ottoman Architecture matures until the sixteenth century during which it attains perfection. The process of decline started in the seventeenth century (Baydar, 2004).

\section{Recent Shift In Turkish Architecture}

There seen a change in the approach in the recognition of an architect and architecture by the Westernization. The architect who previously had been considered as member in a guild of building activity started to be esteemed as "an entity".

A "Self"-centred system, where the individual designers are prominent figures, have emerged due to the increase in the individualistic designs (Ödekan, 2009: 47). Conjointly, there also seen a shift from the education conducted by the "Hassa Mimarlık Ocağı" or Sultan's architectural chamber and by the builders guild towards a formal architectural education disturbing the balance between the ethical-moral codes and technical learning outcomes.

In this Europeanization period Ottomans have introduced modern educational systems and have initiated military, engineering, veterinary, architectural and fine arts schools to transfer new ideologies and value judgements in philosophy, arts, architecture, decoration etc.

New institutions, such as, post offices, train stations, banks etc. and new needs also emerged a shift from the classical architectural education and organization like Hassa Mimarlık Ocağı on which hesitations on the efficiency of the classical educational manner had been aroused (Yavuz, 2009).

Here a complete shift is observed from apprenticemaster relation to the academic education.

During the reign of Selim III Military Engineering schools opened. In 1884 the first civilian Hendese-i Mülkiye Mektebi or Engineering School with five years education had introduced taken the French school, Ecole des Pontes et Chaussees as a model and European teachers recruited (Karaca, 2012: 156). Architecturel courses were given in the Engineering Schoos.

Ebniye-i Hassa replaced Hassa Mimarlar Ocağı. Its Director Abdulhâlim Efendi has appeal Sultan the need for a civilian architectural school where "fenn-i mimâri" or art of architectural courses will be given and he received the grand of the sultan (Turan, 1963: 179). By the effords of Osman Hamdi Bey the Museum Director and Nazır Suphi Paşa the Trades Minister in 1881 Sanâyi-i Nefîse Mekteb-i Alisi The first Higher Fine Arts School was established (Turan, 2012: 179)

The first formally educated architects were graduated from this school.

This movement is the main and the greatest gain in terms of "Academical Architectural Education" in Turkey.

There was a clear distinction between the studio education in the Fine Arts School "Sanayi-i Nefise Mektebi". While Giulio Mongeri was teaching and designing "ideal and pretensious" projects, Vedat Bey, the first Turkish architectural studio mentor and his students were in more "realistic" side (Eldem, 1983: 11).

1. First Nationalistic Movement Architecture

One of the first graduates of this formal academical architectural education Mimar Kemalettin and its first Muslim Ottoman teacher Mimar Vedat have started a new movement towards the new interpretation of the Classical Ottoman Architecture against the widely applied European styles specially by the foreign architects and non-Muslim Ottoman subjects builders. 
This movement is called the First National Architectural Style which find many followers still today.

In the early period of Republican Architecture this First Nationalistic vision/movement in architecture which somehow can be considered a neo classical interpretation of Traditional Turkish Architecture started during the late late Ottoman period have strenghten by the new ideology of the Republic of Turkey and constitute the new Architecture of Ankara.

There is another movement from Europe to Turkish lands during and after the first World War. The four architects took place in the architectural arena of the Republic of Turkey as instructors, designers, advisors, planners. These were mainly Clemens Holzmeister who built TBMM, Jansen (the urban planner of Ankara), Ernst Egli, Theodor Jost, Martin Wagner, Martin Elsaesser, Bruno Taut who is teaching the Fine Art School, Robert Oerley. The Contemporary movements of Europe was imported to Turkey and Turkish Architectural Education

2. Second Nationalistic Movement Architecture

Another movement which is called the second nationalistic movement during the 1950s. Because of a new attempt had been observed in interpreting the Turkish architecture with the contemporary lines depending on the roots in architectural history, mainly by Sedat Hakkı and Turgut Cansever.

\section{The Gain In Architectural Education}

Contemporary schools and contemporary education around the 1940s maybe 1930s on words still they establish of the Higher Education Council of Turkey.

There are 4 types of education programs in architecture:

1. 2-year program of vocational schools

2. 4-2 year-program of teachers school.

3. 4-5 year-program of academy departments; with arts oriented schools following the State Academy of Fine Arts in Istanbul, and technically oriented schools like the Yildiz Architecture and Engineering Academy in Istanbul.

4. 4-5 year-program of university department where there are the arts and theory oriented schools following American architecture model like art and theory oriented schools in Middle East Technical University (METU) established in 1956, and technically oriented schools like Istanbul Technical University following EcolePolytechnique model as the first architecture and engineering school.

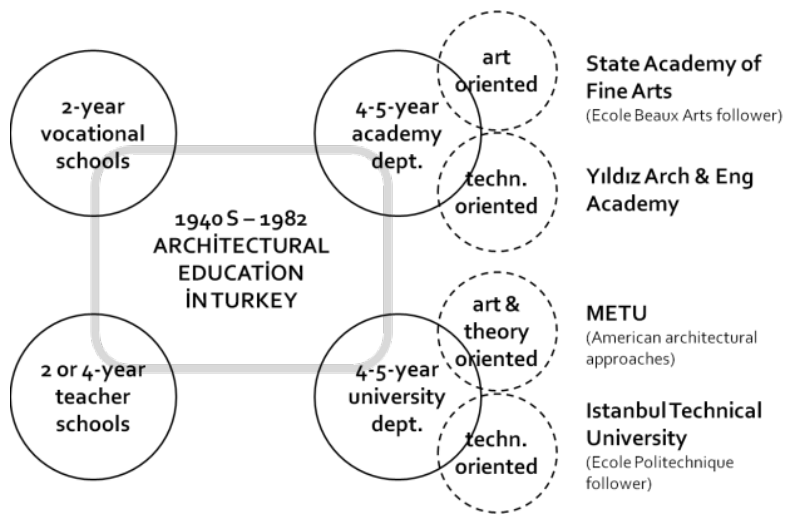

Fig. 4. Four Types of Educational Programs in Architecture.

Then come to the establishment of the higher educational council in Europe. There is abolishment of the academies in university. The 4+2 system is applied, and again there are some distinctions between the art oriented and theory universities and technically oriented schools.

These education sytems, however, changed in 2010 on works under the United European decision in an effort called the Bologna Process. Started with Bologna Declaration signed in 1999, the Bologna Process aims to increase the comparability and readability of degrees across all member state higher education systems ensuring all stakeholders' greater compatibility and comparability in the systems of higher education in all of EU member countries. Turkey participated to Bologna Process since 2001 and it is turned into a formal process for the country with the Council of Higher Education (YÖK) being the primary institution responsible from the implementation of Bologna Process.

The Bologna Process is started to be applied in all 82 architecture schools in Turkey. This broad unity in teaching methodologies learning outcomes for the university. What are the games here? The games the systematical education set of learning outcomes in parallel word UNESCO, UIA and EU integrating to the word architectural education.

The gain during this process are the provision of systematic architectural education, equipped with a set of well-defined learning outcomes. This change brings the mass education, very little architectural ethics is embedded in courses. Students are assessed only on courses. Teachers can not be parenting any ethical approach to any student or graduate. In short terms, they do not know the characteristic of students. There are coming as masses and graduated as masses. They can not nurture of the students' ethics.

\section{The Loss In Architectural Education}

Return to Ottoman architectural education to analyze what has been lost. The Turkish-Islamic architecture, especially Ottoman Architecture, is the result of a great composition that originates from the common spirit of society. But regrettably, the artist/architect, who brought this composition into being out of traditions related with an oral cultural understanding, and this oral ottoman education very few little written sources have reached 
today from the ottoman time. So of the books out there are Teziretul Bunyan of Sai Mustafa Celebi the narration of Mimar Sinan and Risale-I Mimariyye was about Mehmet Aga, the architect of Sultan Ahmet Mosque by Cafer Efendin in (1614) from these we clearly convinced that Mimara Haca Ocag Sultan's Architectural Chamber had great role in Architectural Education during The Ottoman era.

The talented youngsters were admitted as apprentices and being educated by the more experienced ones. The apprentice-master educational system was accepted during the Ottoman Era. Besides, the on hand education drawing, perspective-elevation, mathematics and geometry were being thought as theoretical system. The value/moral systems of the society and in depth belief education was essential in the education of these youngsters.

After a certain level of experience and many tests in morals and ethics, they were promoted to affiliated and then to full tenured masters and Chief Architects. Some of these selected among these chief architects (Turan, 1963) for a lifetime duty have been selected SerMimarân-1 Hassa or the Chief of Court Architect, such as, Mimar Hayreddin, Mimar Sinan, Davud Ağa, Dalgıç Ahmed Ağa, Sedefkâr Mehmed Ağa, Kasım Ağa, and Mehmed Tahir Ağa.

On the other hand as the other guilds also in the architect built them guilds a moral ethics religious and especially Sufism studies were essential in shaping their students and members. In the proceeding in the conference ceremony of the sultan, on the left hand side the guild's member carrying a model of Suleymaniye mosque and the procession.

The book of Mimar Sinan mentions, "It can be deduced that as long as man, as the domain of heart and soul, does not build the pavilion of his existence and does not decorate the 'mosque of the heart' with the tapestry of the beauty of good morals, and make it flourish, he cannot make his environs flourish either" (Crane \& Akin, 2006).

\section{Return To The Spirit}

According to Islamic thought, as intellect, the heart and the spirit determine the perfection of a human being, one advances on the endless path to perfection, acquiring knowledge, refinement and wisdom, according to depth one gains in this direction. (Numan,2017)

According to the Islamic thought like has it state in the verse 89: 28 .

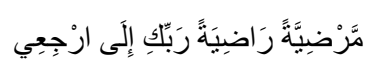

Come back thou to thy Lord, well pleased (thyself), and well pleasing unto Him.

Table 1. Stations on the Path to Perfection.

\begin{tabular}{|l|l|l|}
\hline Intellect & Heart & Spirit \\
\hline Knowledge & Refined Knowledge & Wisdom \\
\hline Skill & Refined Taste & Meaning \\
\hline
\end{tabular}

As intellect, the heart and the spirit determine the perfection of a human being, one advances on the endless path to perfection, acquiring knowledge, refinement, and wisdom, according to depth one gains in this direction. Can these stations on the path to perfection be applied to the artisan and architect, or even to edifices, in Islamic art and architecture?

The ones Who surpasses intellect, and searching for beautiful taste in the direction of the inspiration of their heart and soul, surpasses the technical knowledge and skill that can be acquired through intellect! There is another step beyond this refined taste, and that is only for an edifice that has reached the level of meaning that a sage architect, by his wisdom has seized, collecting it from the spiritual depths thatbelong to the "True Artist"

The adopted common meaning and beautiful taste expressed sometimes an idea, sometimes as a perception or concept of civilization, determines societal life comprehensively and will command society in all its parts ofits part, it's a fact. In arts too, including in architecture, which the idea of Unity that dominates Ottoman Society's thought and its deeper comprehension and the tune of this idea were reflecting the education in totality, including the architectural education, and was consequently embodied in every kind and expression of art and Architecture (Numan, 2017).

\section{References}

Baydar, G. (2004) Journal of Architectural Education. "The Cultural Burden of Architecture", pp. 19-27.

Crane, H. \& E. Akin (2006) Sinan's Autobiogrphies: Five sixteenth-century texts. Leiden: Brill.

Efendi, C. (1987) Risale-I Mi'mariyye: An early Seventeenth Century Ottoman Treatise on Architecture, Leiden: E.J. Brill.

Eldem, S. H., 1983. Sedad Hakkı Eldem 50 Yıllık Meslek Jübilesi. Mimar Sinan Üniversitesi 100. Y1ldönümü Armağanı, Mimar Sinan Üniversitesi Yayını, İstanbul.

Freely, J. (2011) A History of Ottoman Architecture. WIT Press: Southampton.

Karaca, M. ve diğ. (2012) İstanbul Teknik Üniversitesi ve Mühendislik Tarihimiz, İstanbul Teknik Üniversitesi, İstanbul.

Nalbantoğlu, G. (1988) "The Birth of an Aesthetic Discourse in Ottoman Architecture", Middle East Technical University Journal of Architecture, vol 8.2. pp 115-122.

Ödekan, A., (2009) "Zanaatan Mimarlığa Doğru/From Craft to Arcitecture", Mimar Kemalettin ve Çă̆l, TMMOB Mimarlar Odası ve Vakıflar Genel MüdürlüğüOrtak Yayını, Ankara, pp. 47-52.

Pamir, H. "Architectural Education in Turkey in its Social Context". in Architectural Education in the Islamic World, Ahmet Evin (ed.). Singapore: Concept Media/Aga Khan Award for Architecture.

Sey, Y. and Tapan, M (1983) "Architectural Education in Turkey: Past and Present”, Mimar 10: pp. 69-75. 
Turan, Ş. (1963), "Osmanli Teşkilatında Hassa Mimarlari" in Ankara Universitesi Dil ve TarihCografya Fakultesi Dergisi, vol. I, issue 1, pp. 157202.

Yavuz, Y. (2009). Imparatorluktan Cumhuriyete Mimar Kemalettin 1870-1927, TMMOB \& Vakiflar GM Yay, Ankara. 